Cahiers $d u$ MONDE RUSSE

\section{Cahiers du monde russe}

Russie - Empire russe - Union soviétique et États indépendants

$59 / 4 \mid 2018$

Varia

\title{
The Soviet Afro-Asian Solidarity Committee and Soviet Perceptions of the Middle East during Late Socialism
}

Le comité soviétique de solidarité afro-asiatique et les perceptions soviétiques du Moyen-Orient à l'époque du socialisme tardif

\section{Philipp Casula}

\section{(2) OpenEdition}

\section{Journals}

Electronic version

URL: https://journals.openedition.org/monderusse/10542

DOI: 10.4000/monderusse. 10542

ISSN: $1777-5388$

Publisher

Éditions de l'EHESS

Printed version

Date of publication: 1 October 2018

Number of pages: $499-520$

ISBN: 978-2-7132-2747-9

ISSN: $1252-6576$

\section{Electronic reference}

Philipp Casula, "The Soviet Afro-Asian Solidarity Committee and Soviet Perceptions of the Middle East during Late Socialism", Cahiers du monde russe [Online], 59/4 | 2018, Online since 01 January 2022, connection on 08 January 2022. URL: http://journals.openedition.org/monderusse/10542 ; DOI: https://doi.org/10.4000/monderusse.10542 


\title{
THE SOVIET AFRO-ASIAN SOLIDARITY COMMITTEE AND SOVIET PERCEPTIONS OF THE MIDDLE EAST DURING LATE SOCIALISM
}

\author{
"Well, Seriozha, it's not easy to be the first one. \\ The first one starts something big and honourable. \\ And we are right to be proud of it. But from then \\ on we pay a heavy price, from then on it costs us dearly."
}

Proshu slova, 1975

The Soviet Afro-Asian Solidarity Committee (SKSSAA) was established in May 1955. ${ }^{1}$ It received offices close to the Ministry of Foreign Affairs, ${ }^{2}$ at 10 Kropotkina Street (today Prechistenka). The yellow mansion had previously belonged to Count Ivan Odoevskii and Decembrist general Michail Orlov. It housed the Jewish Anti-Fascist Committee until the Solidarity Committee took up residence. ${ }^{3}$ The SKSSAA operated at the fringes of official foreign policy and filled the gaps left by other Soviet institutions. It developed specific views and peculiar perspectives on the Middle East and on the developing world in general.

I thank the anonymous reviewers for their insightful suggestions and comments. Also, I would like to thank Denis Volkov, Natalia Telepneva, and Vera Tolz for their careful reading of early drafts of the paper, and Jessica Mijnssen for the invaluable proofreading.

1. Samandar Kalandarov, "Dorogi Solidarnosti [Paths of Solidarity]", https://rossnaa.ru/ way-solidarity.html; However, the first meeting of the Presidium of the Solidarity Committee convened on November 1, 1956, presided by renowned Tajik poet Mirzo Tursun-Zade, cf. Masha Kirasirova, "Sons of Muslims in Moscow: Soviet Central Asian Mediators to the Foreign East, 1955-1962,” Ab Imperio, 4 (2011): 123.

2. Later, on nearby Kropotkinskii pereulok, half-way between the SKSSAA's mansion and the Foreign Ministry, the Palestine Liberation Movement received its "embassy" in Moscow, Otnosheniia Rossii i Palestiny, Dos'e [Relations between Russia and Palestine, dossier], http:// tass.ru/info/902298; see also GARF (Gosudarstvennyi Archiv Rossiiskoi Federatsii), f. 9540, op. 1, d. 433, Zapisi besed, informatsii iz arabskikh stran [Records of conversations, information from Arab countries] (23.12.1977-16.12.1978), 1. 31-35.

3. Uznai Moskvu [Discover Moscow], https://um.mos.ru/houses/dom_generala_orlova/ 
The Solidarity Committee was specifically tasked with interacting with liberation movements and other foreign non-state organisations with which neither the CPSU International Department nor the Ministry of Foreign Affairs had direct relationships. The range of activities was very broad, involving cultural as well as political tasks. These included public diplomacy, political and material support, the organisation of conferences and meetings at various levels and on different topics, the mobilisation of the Soviet population and expressions of solidarity in the context of the many proxy conflicts of the Cold War, and the education of foreign cadres. ${ }^{4}$ Of particular importance were scholarships for Soviet universities, which the Solidarity Committee awarded to members of its partner organisations, and which made cooperation with the SKSSAA particularly attractive to foreign partners. To this aim, the Solidarity Committee cooperated with the Ministry of Education. It also cooperated with Soviet embassies, the Academy of Sciences, and other Soviet public organisations such as the Union of Friendship Societies (SSOD), the Soviet Committee for the Defence of Peace, the Soviet Women's Committee, the Committee of War Veterans, and the unions. All the international activities of these bodies were coordinated by the International Department of the CPSU, which had a very strong influence on the SKSSAA. ${ }^{5}$ Nevertheless, long-time secretary Aleksandr Dzasokhov claimed that the SKSSAA enjoyed some intellectual independence and had disagreements with the Central Committee. Especially in its interactions with foreign intellectuals, it needed to at least appear intellectually autonomous and more "flexible" than state and party officials. ${ }^{6}$ In fact, its staff often comprised Soviet intellectuals, especially from Central Asia or the Caucasus. ${ }^{7}$ In short, the SKSSAA was one of the many institutions and agencies with which the Soviet Union could meet global challenges after the Second World War. It was also one of the Soviet bodies that engaged in what could be considered public diplomacy for the "hearts and minds" of the people, something that Soviet diplomacy claimed to have aimed for early on. ${ }^{8}$

4. Kalandarov, "Dorogi Solidarnosti."

5. Karen Brutents, Tridtsat' let na staroi ploshchadi [Thirty Years on the Old Square] (M.: MO, 1998), 163; Leonard Schapiro, "The International Department of the CPSU: Key to Soviet policy”, International Journal, 32 (1977): 43.

6. Aleksandr S. Dzasokhov, Chelovek i politika [Man and Politics] (M.: Rossiiskaia Gazeta, 2009), 30. In contrast, Robert Hornsby argues that the Komsomol was characterized by "its lack of political agency," and that it was an "unashamed" "handmaiden to the [...] Communist Party," neglecting any heterogeneity within the Party itself. Robert Hornsby, "The post-Stalin Komsomol and the Soviet fight for Third World youth," Cold War History, 16, 1 (2016): 87. Dzasokhov, however, claims that his organization had more leeway and its own, distinctive approach to foreign affairs.

7. Their participation in the SKSSAA echoed a Soviet belief dating from the 1920s that "marginalized minorities could suddenly envision themselves at the forefront of both modernism and revolution," cf. Steven S. Lee, The Ethnic Avant-Garde (New York: Columbia UP, 2015), 2.

8. A socialist, new, open diplomacy directed not only to governments, but also to a wider public: Iurii Arbatov, “Diplomatiia v bor'be za umy liudei,” Kommunist, 18,12 (1966): 118. 
The SKSSAA began operating at a time of Soviet heightened awareness of the decolonising world. The Soviet Union had emerged from the Second World War as a major power in need of new allies in the Cold War. Its rediscovery of the "Third World" also necessitated a reorganisation of knowledge. The $20^{\text {th }}$ Congress of the CPSU in 1956 called to reengage with the "Third World." Anastas Mikoyan accused the Institute of Oriental Studies of "dozing contentedly, while the entire East has awakened," and demanded regional expertise that could serve political ends. ${ }^{10}$ The establishment of the SKSSAA can be seen in this wider context of engagement with the decolonising world and the identification of colonialism and imperialism worldwide as a "common enemy." 11

A tight relationship developed between the Soviet Union and the Middle East, ${ }^{12}$ particularly with Egypt. ${ }^{13}$ Therefore, this paper will especially but not exclusively draw on sources concerning this wider region, bearing in mind that the "East" is not only a specific geographic place, but denotes a particular relationship, a power gap, as suggested by Edward Said's Orientalism. This also applies to the Russian use of vostok (East). ${ }^{14}$ Regarding the time-frame of this study, the paper will focus particularly but not exclusively on the 1960s-1970s: this period represents a crucial phase in Soviet relations to the "Third World" and the Middle East during which enthusiasm faded, and pragmatism set in. ${ }^{15}$ While stagnation (zastoi) characterised the internal status quo in the USSR, and only "crises and mutual disillusion" 16 set the tone in the relation with the developing world, Soviet ideologues and the Solidarity

9. Anastas Mikoian, "Rech' tov. Mikoiana [Mikoyan's speech]," XX. S"ezd kommunisticheskoi partii Sovetskogo Soiuza, Stenograficheskii otchet, vol. 1 [20 $0^{\text {th }}$ session of the Communist Party of the Soviet Union, stenographical report] (M.: 1956), 324.

10. Petr Cherkasov, IMÉMO. Portret na fone épokhi [IMĖMO. A portrait against the backdrop of an era] (M.: Ves' Mir, 2004), 101-103; Odd Arne Westad, The Global Cold War (Cambridge: Harvard UP, 2007), 69.

11. Westad, Global Cold War, 67.

12. Mohamed Heikal, The Sphinx and the Commissar: The Rise and Fall of Soviet Influence in the Middle East (New York: Harper \& Row, 1973).

13. Nasser's first visit to Moscow deeply impressed Khrushchev, cf. Mohamed Heikal, The Cairo Documents (New York: Doubleday \& Co., 1973), 123-124. Egypt was also the first Middle Eastern country that signed a cultural cooperation agreement with the USSR, cf. Constantin Katsakioris, "Soviet Lessons for Arab Modernization," Revue d'histoire européenne contemporaine, 8, 1 (2010): 91-92.

14. Vostok (East) in Russian can be arabskii, musul'manskii, zarubezhnyi, and blizhnii, srednii or dal'nii [Arab, Muslim, Foreign, Near, Middle, Far]. As Masha Kirasirova highlights, Vostok was a flexible and vague term. Any oppressed people could be qualified as "Eastern." Masha Kirasirova, "The East as a Category of Bolshevik Ideology and Comintern Administration," Kritika, 18,1 (2017): 7-34.

15. Alexei Vasil'ev, Rossiia na blizhnem i srednem vostoke. Ot messianstva $k$ pragmatizmu [Russian in the Near and Middle East. From messianism to pragmatism] (M.: Nauka, 1993).

16. Alexey Vasiliev, Russia's Middle East Policy: From Lenin to Putin (London: Routledge, 2018), 44 . 
Committee outwardly clung to revolutionary dreams and projected a revolutionary spirit onto the "East." 17

\section{State of the art and conceptual considerations}

This paper is placed within an emerging tradition of research that addresses East-East encounters and Soviet public organisations, especially in the context of interaction with international bodies and administrations. In contrast to other works, however, this paper will more explicitly add a Saidian perspective to these relations and bring to light the modes of representations and the power gap between the two sides. Constantin Katsakioris has traced the uneasy relation between African and Soviet intellectuals and stressed how unhappy Soviet officials were with heterodox socialist views and the overall decreasing importance of ideology in Soviet education to foreign students. ${ }^{18}$ Andreas Hilger has demonstrated the tensions and limitations of Soviet efforts in the developing world, ${ }^{19}$ and more recently analysed the activities of Soviet students in India. ${ }^{20}$ Ragna Boden has written an extensive cultural history of Indonesian-Soviet relations, highlighting the importance of Soviet regional expertise and knowledge. ${ }^{21}$ Tatiana Smirnova and Ophélie Rillon have published on the role on Soviet women's committees and their exchange with African countries. ${ }^{22}$ Robert Hornsby has discussed the work of the Komsomol abroad as a "distinctive part of the Soviet Cold War struggle," and implicitly pointed out Soviet decision makers' essentialist views of the East. ${ }^{23}$ Julie Hessler has focussed on "Third World" students at Soviet universities through the 1960s and 1980s, stressing that cultural difference and racism shaped their

17. To some degree this resembled a "postcolonial Orientalism," i.e., the projection of revolutionary fantasies onto the East, cf. Lisa Lowe, Critical Terrains: French and British Orientalism (Ithaca: Cornell UP, 1991), 146-189.

18. Constantin Katsakioris, "L’Union soviétique et les intellectuels africains," Cahiers du Monde russe, 47, 1-2 (2006): 15-32; Constantin Katsakioris, "Une superpuissance éducative. L'Union soviétique et la formation des élites du tiers-monde," Traverse - revue d'histoire, 25, 1 (2018): 119.

19. Andreas Hilger, Die Sowjetunion und die Dritte Welt: UdSSR, Statssozialismus und Antikolonialismus im Kalten Krieg 1945-1991 (Munich: R. Oldenbourg, 2009).

20. Andreas Hilger, "Nationale Entwicklung, sozialistischer Internationalismus und bilaterale Untiefen. Der sowjetisch-indische Studierendenaustausch in den 1950er- und 1960er Jahre," Traverse-Revue d'histoire, 25,1 (2018): 119.

21. Ragna Boden, Die Grenzen der Weltmacht (Stuttgart: Franz Steiner, 2006).

22. Tatiana Smirnova and Ophélie Rillon, “Quand des Maliennes regardent vers 1'URSS (1961-1991)," Cahiers d'études africaines, 226 (2017): 331-354.

23. Since Moscow would allegedly "bear rather limited comparison to their own situation at home", cf. Robert Hornsby, "The post-Stalin Komsomol," 92. It is unclear whether this is Hornsby's own or the Komsomol's essentialisation. 
interaction with their Soviet environment. ${ }^{24}$ Masha Kirasirova has argued that the Soviet Union instrumentalised religion and assumptions about Eastern culture for the purposes of cultural diplomacy in the Middle East. ${ }^{25}$

The topics close to those Edward Said touched upon in his discussion of Orientalism notwithstanding - ideology, education, knowledge, expertise, and religion, most of these works forego the Saidian notion of Orientalism. Orientalism is mainly deployed in literature on the Russian and Soviet internal East, Central Asia and the Caucasus. It is almost exclusively used for the imperial period, and often to incendiary effect. ${ }^{26}$

The omission of Orientalism in the discussion of external relations in the Soviet era has created two consequences: first, analyses undertaken so far are less aware of the modes of representation of the Other in the interactions they have described; instead, they are concerned with the What, When and Why Of Soviet relations with the abroad, and to a lesser extent with the How. Secondly, they have taken the power and knowledge gap in these interactions as a given. It is, however, precisely this gap that influences the How of these relations and has produced Orientalist patterns of representation of the Other, and, equally importantly, of the Self. ${ }^{27}$ Orientalism is understood here as an "institution for dealing with the Orient - dealing with it by making statements about it, authorizing views of it, describing it, by teaching it, settling it, ruling over it." ${ }^{28}$ This has changed over time and developed various ramifications, principally in content (and less so in form). Orientalism is a "travelling concept," ${ }^{29}$ a "network of aesthetic, economic, and political relationships that cross national and historical boundaries." $" 30$

The Soviet Afro-Asian Solidarity Committee contributed to such an activity of describing, teaching and ruling over the East. It engaged in undertakings aimed at "politically, sociologically, militarily, ideologically, scientifically, and

24. Julie Hessler, "Death of an African Student," Cahiers du Monde russe, 47,1-2 (2006): 33-64.

25. Kirasirova, "Sons of Muslims," 108.

26. David Schimmelpenninck van der Oye, Russian Orientalism (New Haven: Yale UP, 2010); Vera Tolz, Russia's Own Orient (Oxford: Oxford UP, 2011); Nathaniel Knight, "Grigoriev in Orenburg, 1851-1862: Russian Orientalism in the Service of Empire?;" Slavic Review, 59,1 (2000): 74-100; Adeeb Khalid, "Russian History and the Debate over Orientalism," Kritika, 1, 4 (2000): 691-699; David Schimmelpenninck van der Oye, "The Curious Fate of Edward Said in Russia," Études de lettres, 2-3 (2014): 81-94.

27. In contrast to Kirasirova, "Sons of Muslims," this paper follows Tolz, Russia's Own Orient, and distinguishes between the Saidian Concept of Orientalism and the discipline of Orientology, or Oriental Studies (Vostokovedenie). Cf. also Masha Kirasirova, "Orientologies compared," in Michael Kemper \& Artemy M. Kalinovsky, eds., Reassessing Orientalism: Interlocking Orientologies during the Cold War (London: Routledge, 2015), 16-46.

28. Edward Said, Orientalism (New York: Penguin, 2003), 3; Bryan S. Turner, Orientalism, Postmodernism \& Globalism (London: Routledge, 1994), 96.

29. Timothy Brennan, "The Illusion of a Future: Orientalism as Traveling Theory", Critical Inquiry, 26; 33 (2000): 558-583.

30. Ali Behdad, "Orientalism matters,” MFS Modern Fiction Studies, 56, 4 (2010): 709-728. 
imaginatively" 31 producing a specific, potentially revolutionary or socialist East. The Soviet conception of the East (as potentially socialist) set the content of Soviet Orientalism apart from other European variations. Soviet Orientalism was dissimilar to its European cousin: the Soviet, socialist Self was modern and drew upon similar conceptions of modernity and modernization ${ }^{32}$ as the West without being Western, the Other was backward, but potentially politically similar to the Self. The Other was conceived as a potential ally, as able to effect (revolutionary) change and capable of progressive transformation. However, the forms of Western and Soviet Orientalism were similar: both acted from a position of power, of superior military and financial means, technology, and knowledge. Both Soviet and European variants of Orientalism portrayed themselves as the subjects and not the objects of description and analysis, both were the omniscient observers whose assessments mattered. This power gap is also reflected in the documents of the Solidarity Committee. The SKSSAA passed judgements and earmarked funding and support, while the partner movements and organisations had to be the "good object of knowledge, the docile body of difference, that reproduces a relation of domination." ${ }^{33}$ Both forms of Orientalism objectified the Other and produced information about it, however, the focus of the SKSSAA's assessments was often more political than cultural.

The Solidarity Committee was at the frontline of this meeting between the socialist Self and the Other, which was considered to strive for socialism. It constantly engaged in the evaluation of socialist progress, in the assessment of movements and of whether its representatives were faithful to the Soviet position. Still, this interaction may also have been responsible for producing a hybridisation: ${ }^{34}$ the history of Imperial Russia and the Soviet Union is particularly illustrative of this hybridisation. The SKSSAA was in itself a meeting point of East and West, a hybrid, a product of encounter. Soviet Easterners worked prominently within its ranks, ${ }^{35}$ and their presence also helped counter Chinese claims that the USSR, too, was a "white, industrialized, imperialist power." ${ }^{36}$ Thus, Saidian Orientalism must be historicised and contextualised: there is no acting out of a predetermined Orientalist script. ${ }^{37}$ The SKSSAA answered Mikoyan's call for applicable knowledge on

31. Said, Orientalism, 3.

32. The economic and educational initiatives advanced by the Soviet Union in the Middle East and elsewhere in the decolonising world bear witness of this kinship between eastern and western Orientalisms, Katsakioris, "Soviet Lessons for Arab Modernization."

33. Homi Bhabha, The Location of Culture (London: Routledge, 1994), p. 31.

34. Patricia Almarcegui, "Orientalism and Post-Orientalism”, Quaderns de la Mediterrània, 20-21, 2014, p. 141.

35. Kirasirova, "Sons of Muslims". It is doubtful to which extent their "Oriental" identity was the most preeminent one for these officials, or whether they saw themselves mostly as representatives of the USSR as a whole.

36. Jeremy Friedman, "Soviet Policy in the Developing World and the Chinese Challenge in the 1960s", Cold War History, 10, 2 (2010): 263.

37. Vera Tolz, Russia's Own Orient (Oxford: Oxford UP, 2011), p. 22. 
the East. Soviet policy makers tried to grasp the "Third World's" role in a global revolutionary context: where to concentrate revolutionary efforts, how revolution would (or not) occur, and with whom to close alliances. ${ }^{38}$

One of the lenses through which the USSR gazed and evaluated the Middle East was the SKSSAA. Its gaze was that of a powerful donor. However, the SKSSAA also depended upon its partners. It was these partners and their success that gave the Solidarity Committee legitimacy and a raison d'être. Hence, the present analysis of the SKSSAA will focus on how representation of the "Third World," particularly the Middle East, worked, on the knowledge it produced about "Third World" partners but also about the Soviet Union itself. It will also focus on the way power was exercised and highlight the SKSSAA's disciplinary functions as it continuously assessed, rewarded, and punished individuals and movements. Through close readings of reports, telegrams and communiqués, the paper will unfold how the East appeared through the lens of the SKSSAA collaborators, how the latter participated in constructing Soviet, Eastern, and Western identities.

\section{Crafting identities: friends and foes in a conflict-ridden place}

The SKSSAA must be seen as a site where both Soviet and Eastern identities were crafted. In line with key assumptions of Orientalism, the East was not a place but a project $^{39}$ - i.e., a "vision and a construction" 40 - in which identities were constantly produced and reproduced, in which plans for development were made and remade. The SKSSAA contributed to the production of the image of the Soviet Self and of a potentially socialist Eastern Other, but also to the notion of the common enemy, the West and Israel in particular. It offered "an alternative discourse on the health of the socialist struggle and an often-compelling narrative on the country's chief ideological" enemies. ${ }^{41}$

From the many exchanges and communications from and with the SKSSAA, it becomes evident that the Solidarity Committee and its respective interlocutors participated in the construction of friends and enemies, reassuring each other and themselves about their place in the world. It was the SKSSAA that seemed to know exactly who the foes and friends of "the Arabs" were and that seemed to play a more active part in this identity construction due to the nature of the relationship, in which it was the main sponsor. "Arab unity" and the "brotherly" relationship between all nations living in the Middle East, the Solidarity Committee's key concerns, were a projection onto the relations between the peoples of

38. Galia Golan, Soviet Policies in the Middle East from World War Two to Gorbachev (Cambridge: Cambridge UP, 1990), 212-213.

39. Vijay Prashad, The Darker Nations (New York: The New Press, 2007), xv.

40. Bhabha, Location of Culture, 3.

41. Hornsby, "The post-Stalin Komsomol," 86. 
the Arab East of Soviet nationalities policies, ${ }^{42}$ that is, peaceful coexistence under a socialist setup.

In a routine letter to the leadership of the Yemeni National Front, the Presidium of the SKSSAA enumerated many key enemies of both the USSR and Arab unity. The Presidium congratulated their comrades on the many "successes achieved in the fight for the liquidation of imperial domination [...] the just fight of the people of Democratic Yemen receives the ongoing and widest support of the Soviet Union [...] The Soviet people are sincerely happy about the achievements of the PRY [People's Republic of Yemen] in building a new life." ${ }^{43}$ Hence, the USSR placed itself in the anti-imperialist camp and assured its interlocutors of Soviet support, without going into details about what this support consisted of. The letter went on to reassure the Yemeni comrades that they were indeed "building a whole new life" leading to freedom and social progress. At the time of this letter, in 1973, South Yemen was three years old and had received vast support from various countries of the socialist bloc.

A key foe, which reappeared time and again in the SKSSAA letters, was Israel. Especially in 1973, the Yom Kippur War, and the Israeli-Palestinian conflict played out in Lebanon, ${ }^{44}$ triggered a flurry of solidarity messages. In April, the SKSSAA expressed "anger and indignation about new crimes the Israeli military clique" committed in Lebanon and denounced the "violence and terror committed by Israeli ruling circles." 45 The statement, addressed to Yasser Arafat, was surprisingly careful not to condemn Israel as a state but pointed to its "military establishment." Indeed, the USSR supported Security Council Resolution 242, which implied the recognition of Israel in its borders prior to the Six-Day War. The letter did not condemn Zionism as a movement, although the latter had been criticised elsewhere. Several months later, the SKSSAA again denounced the "criminal acts" of Israeli "aggressive military circles" (voenshchina), "Israeli expansionists" or "Israeli ruling circles" in an official statement. This description, however, drew a clear line between an anonymous Israeli military apparatus on the one hand, and Arab civilians on the other: the document explicitly mentioned that crimes had been committed against the "peaceful population of Syria." 46 The SKSSAA claimed that these acts had allegedly triggered a strong emotional reaction in the Soviet public, namely "anger and fury," which reflected Soviet views of Arab expectations of an adequate reaction. When the Yom Kippur War with Israel broke out in October 1973, the SKSSAA remained faithful to this line of argument. It condemned the "barbarous attacks of Israeli aircraft against peaceful units in Egypt and Syria," the "bombardments Arabian [sic] towns resulting in suffering for civil population,"

42. Kirasirova, "Sons of Muslims," 124.

43. GARF, f. 9540, op. 1, d. 355, 1. 24.

44. William C. Cleveland \& Martin Bunton, A History of the Modern Middle East (Boulder: Westview, 2009), 383.

45. GARF, f. 9540, op. 1, d. 355, 1. 26.

46. GARF, f. 9540, op. 1, d. 355, 1. 37-38. 
and mourned the "victims [who] are peaceful people, women, children, old-age persons." ${ }^{47}$ This statement, juxtaposing an anonymous Israeli military machine on the one hand with Arab civilians on the other, was then published in the Soviet press and sent to various countries. ${ }^{48}$

As the SKSSAA endeavoured to convey the idea that the USSR was a champion of Arab unity, it had to confront the many divisions that seemed to persist in the Middle East. This led to messages in which the SKSSAA claimed to speak on behalf of a whole nation. In a telex written in French to Kamal Jumblatt, leader of the Lebanese Druze community and head of the Lebanese Afro-Asian Solidarity Committee, SKSSAA Secretary Aleksandr Dzasokhov voiced concern about the new violence taking place in Lebanon in late 1975: "mesures destinées arrêter fusillade et normaliser situation entreprises gouvernement libanais soutenues activement forces nationales patriotiques chaleureusement approuver tous amis peuple libanaise [...] sans aucun doute processus normalisation situation Liban répond aspirations nationales peuple libanais" [ $\mathrm{sic}] .{ }^{49}$ The SKSSAA thus claimed to represent the whole of the national interest of Lebanon, in keeping with Said's critique of Orientalism that the East cannot represent itself. ${ }^{50}$

Conversely, the SKSSAA rejoiced when "brotherly people" were able to achieve a compromise: "The Soviet Afro-Asian Solidarity Committee cordially congratulates national peace solidarity council Iraq, entire friendly Iraqi people on their anniversary signing agreement just settlement Kurd problem. This agreement which put end fratricidal war between Arabs and Kurds, delivered a heavy blow to plans of imperialism and reaction striving disrupt Iraqi peoples ranks" [sic]. ${ }^{51}$ The SKSSAA, hence, presumed to know exactly who was or should be a "brother" to whom. The Soviet Union's own interest in maintaining peace in the Middle East was thinly veiled, as this brotherly unity "delivered blows to imperialism."

Still, the SKSSAA had to face many divisions in the ranks of its Middle East partners. When members of the Afro-Asian People's Solidarity Organisation (AAPSO) discussed whether to move its headquarters away from Cairo to either Tripoli or Damascus after the Camp David Accords, the SKSSAA repeated its "well-known position that the question about the headquarters should be solved democratically, taking into account all its aspects and position of all interested sides." However, "if Syria takes the initiative to invite AAPSO to Damascus, it will face understanding and support from the SKSSAA." 52

47. GARF, f. 9540 , op. 1, d. $355,1.40$.

48. GARF, f. 9540 , op. 1, d. $355,1.42$.

49. GARF, f. 9540, op. 1, d. 390, Perepiska s organizatsiiami solidarnosti i chastnymi litsami stran Arabskogo Vostoka po voprosam ukrepleniia druzheskikh sviazei. Aden - Siriia [Correspondence with solidarity organisations and single individuals from countries of the Arab East on the strengthening of friendly relations. Aden-Syria], 1.1.-31.12.1975, 1. 17, emphasis added.

50. Said, Orientalism, 293.

51. GARF, f. 9540, op. 1, d. 355, 1. 17.

52. GARF, f. 9540, op. 1, d. 471, 1. 31. 
Omar al-Hamdi, leader of the All-Arab People's Congress (AAPC), complained to the Solidarity Committee about the influence Libya exercised on single movements of the Palestinian resistance, bypassing the PLO. Additionally, Libya was unhappy about the exclusion of the Iraqi Baath from the AAPC. Al-Hamdi thus asked the SKSSAA to "use its possibilities" to help normalize the relations between the PLO and the AAPC. ${ }^{53}$ In these documents, the Solidarity Committee was keen to present itself to other Soviet agencies as a trusted advisor and impartial mediator in the Middle East.

In early 1987, in the context of renewed fighting in Beirut and the Syrian occupation of the city, as well as a rapprochement between Damascus and Amman, ${ }^{54}$ Naif Hawatmeh, head of the Democratic Front for the Liberation of Palestine (DFLP) and a close ally of the USSR, criticised Syria's Palestine policy for being guided by the "narrow-class interests of the Syrian bourgeoisie," which "displays anti-imperialist positions but practically makes concessions to the imperialists circles and to the Arab reaction". ${ }^{55}$ Hawatmeh's criticism of Syria was echoed by Mustafa Radvan, who paid a visit to 10 Kropotkina Street a month later as a representative of the "People's Front for the Liberation of Palestine - General Command" (PFLP-GC). He likewise called for the USSR to step in, as he ascribed "huge authority" to the SKSSAA among all parties. ${ }^{56}$

In the climate of multiple divisions and infighting that re-emerged in many SKSSAA documents, the Solidarity Committee was keen to show its moderating influence on all parties involved.

\section{Assessing and evaluating individuals and movements}

A permanent task of the SKSSAA was to regularly evaluate the revolutionary, socialist, or even personal credentials of its individual partners or of whole organisations. Here, the Committee's power becomes especially visible: it was the Committee that granted scholarships, medical treatments, or funded trips. By granting or withholding these services, the SKSSAA could also influence the behaviour of its partners. Good, loyal partners in need could also get exceptional

53. GARF, f. 9540, op. 1, d. 471, 1. 53-56.

54. Efraim Karsh, The Soviet Union and Syria: The Asad Years (New York: Routledge, 1988), 91.

55. GARF, f. 9540, op. 1, d. 595, Zapisi besed s obshchestvennymi prestaviteliami i glavami delegatsii demokraticheskikh organizatsii, posetivshikh SKSSAA [Records of conversations with public representatives and heads of democratic organisations visiting the SKSSAA], 16.1.-14-12.1987, 1. 9-12.

56. GARF, f. 9540, op. 1, d. 595, Zapis' besedy s chlenom TsK Narodnogo fronta osvobozhdeniia Palestiny - GK Mustafoi Radvanom [Records of the conversation with the member of the Central Committee of the Popular Front for the Liberation of Palestine - General Command, Mustafa Radwan], 26.2.1987, 1. 31-34. 
support, especially in cases of emergency, while other, less esteemed movements were excluded, which triggered bitter complaints. ${ }^{57}$

The Solidarity Committee evaluated organisations or individuals and received copies of minutes taken at meetings between Soviet embassy officials and members of foreign movements or parties. These records reveal official Soviet interests but also point to the criteria that Soviet officials used to evaluate their partners' reliability. When a delegation of the Moroccan National Union of Popular Forces (UNFP) stayed in Moscow in November 1961, the SKSSAA compiled a detailed report. ${ }^{58}$ The visitors were high-ranking representatives of the UNFP, among them former Premier and Foreign Minister Abdallah Ibrahim and two other former cabinet members. Their government had been sacked in May 1960 for its anti-Western stance. The sacked ministers then joined the UNFP, a left-wing offshoot of the Istiqlal Party formed in 1959. The UNFP would later face repression by the Moroccan government, to which the USSR would turn a blind eye, and pursued trade relations with Morocco. ${ }^{59}$ As diplomatic relations between the two countries had only been established in 1958, the report compiled by the SKSSAA reflects both caution and curiosity.

In this report, an unnamed official goes into details asking her/his interlocutors about the preferences and divisions within the party. Asked "Which imperialism is more dangerous: the French or American one," former Prime Minister Abdallah Ibrahim replied evasively that he did not know which path of development Morocco would follow, the model "of kolkhozes and sovkhozes," the Chinese way or its own path of development. Additionally, he expressed doubts on "peace" as a key driver for communist movements in Morocco and beyond, as decolonisation had turned violent. Ibrahim thus echoed Frantz Fanon's support for anticolonial violence. ${ }^{60}$ Also, surprisingly, the Moroccans were critical of the Soviet development aid and considered the support for building a shipyard as "not corresponding to the people's needs" and the delivery of military aircraft as disruptive for the position of progressive forces within the country. In these frank exchanges throughout the 1960s, the Solidarity Committee's partners seemed to have still had some leverage with which to pressure the Soviet side, hinting that the Chinese

57. The Moroccan Party of Freedom and Socialism bitterly complained to the "Dear [SKSSAA] brothers" about not having been invited to the $5^{\text {th }}$ AAPSO conference in 1972. Tellingly, the complaint was directed to the SKSSAA and not to the AAPSO leadership, GARF, f. 9540, op. 1, d. 328, 1. 73-74.

58. GARF f. 9540, op. 2, d. 40, Otchety o rabote s innostrannymi delegatsiiami i zapisy besed [Reports on the work with foreign delegations and records of conversations], 6.1.-22.12.1961, 1. $149-160$.

59. Yahia Zoubir, "Soviet Policy toward the Western Sahara Conflict," Africa Today, 34, 3 (1987): 17-32.

60. Frantz Fanon, The Wretched of the Earth (New York: Grove Press, 1963), 35. 
could be possible donors as well. The fear of Chinese influence continued to haunt the Soviet side well into the 1970s. ${ }^{61}$

The report concludes with a short $\mathrm{CV}$ and individual assessments of each of the three delegation members, highlighting less the actual characteristics of the Moroccan interlocutors as the way the Soviet side wished them (not) to be. Abdallah Ibrahim, for example, "delivers the impression of an intelligent, educated person. He commands Arabic, French, English, Spanish, and German. He underlined the necessity of decisive, radical means to nationalise foreign capital, carry out land reform and a democratisation of society." He seemed an ideal partner for the Soviets: educated, committed and dedicated to reforms. Other personal qualities included a "good memory, he is precise and tidy, humble and simple during interactions, always sociable." He impressed the SKSSAA, as he "strives to know as much as possible about the Soviet Union. In contrast to the other members of the delegation, he showed huge interest in visiting the Museum of the Revolution and the VDNKh exhibition. He asked for copies of the Selected Works of Lenin and of the history of the CPSU to be sent to him." However, there is a downside to this positive assessment: "He carefully but clearly conveyed that he has a negative view of the Moroccan communist party." Tahri Mukhammad, in contrast, was the only member of the delegation with a positive view of the Moroccan CP. He was described as well informed, knowing his field, as agile and vivid, however he distinguished himself by a lack of precision and had far less interest in visiting the VDNKh, the Museum of the Revolution and the Kremlin. The assessment concluded with a harsh verdict: "Inclined to alcoholic beverages." Finally, Abderrahim Bouabid praised the cooperation with the Soviet Union but did "not hide his bad relationship" with the Moroccan communist party. "He makes the impression of an intelligent person who loves to discuss about various topics," however, "he loses his temper during discussions, while he is logical and reasoned in his arguments; in his exchanges he is unassuming and simple, and sufficiently sociable." Humility and simplicity seemed to be the most desirable traits.

The interest, or lack of it, in Moscow's sightseeing sites, which seem to have been carefully selected, was considered an indicator of political reliability. These sites turned out to be a political test: if the visitor was interested in the USSR's economic achievements, s/he was also interested in economic modernisation with Soviet support; if s/he visited the Museum of the Revolution showing interest, $\mathrm{s} / \mathrm{he}$ could be a political partner. Abdallah Ibrahim did everything "right" and received additional praise for having asked for Lenin's selected works. As for the other two members of the Moroccan delegation, political and personal evaluations are mixed at best. In this report the SKSSAA emerges as an agent of "uninterrupted assessment" of organisations and persons, as an entity performing continuous

61. RGANI (Rossiiskii gosudarstvennyi archiv noveishei istorii), f. 5, op. 66, Deiatel'nost' KNR v Sirii [The activity of the PRC in Syria], 28.3.1973, 1. 159-167. The third secretary at the Soviet Embassy in Damascus, Fomichev, claimed that Chinese efforts did not correspond to the real interests of the Syrians. 
"transcription of individual behaviour," 62 testing, laying traps for its partners and noting minute details about their behaviour in order to prove or disprove their loyalty.

A trip made jointly by the SKSSAA and Union of Friendship Societies (SSOD) to Somalia in 1972 provides additional evidence for this constant testing and assessing of interlocutors. ${ }^{63}$ This visit took place within the context of a crisis in Soviet-Egyptian relations and a Soviet search for new footholds in the region. Relations with the Somali Siad Barre regime were uneasy, loosely ideologically motivated, yet formally deepening, and a treaty of friendship was signed two years later. Between 1964 and 1977, 4,000 Soviet military advisers poured into Somalia, among them twelve generals, and military facilities were established in Berbera and Mogadishu. ${ }^{64}$ When the SKSSAA-SSOD delegation arrived in Mogadishu, it took particular interest in the work of the "Offices for Contacts with the Public" and its "orientation centres," institutions designed to strengthen the central government's authority against the power of local clans. Overall, these offices were deemed to have done a good job in Somalia, according to the Soviet evaluators, building schools, contributing to ideological education of the public, and conducting self-help programmes. However, the report expresses regret that, despite promises to the contrary, the Soviet delegation had had fewer meetings with politicians than expected and that their discussions took place mostly with representatives of the public. These complaints reflect that the SKSSAA and the SSOD had engaged in semi-official diplomacy without being fully-fledged diplomats. The report notes with regret that a state-visit by the president of the Central African Republic (CAR), Jean-Bédel Bokassa, to Somalia had interfered with the delegations' plans to meet Somali officials. This explanation could be read in two ways: either as veiled criticism of the Somali partners, who had not abided by their promises and had given precedence to a CAR representative over the more important Soviet partners, or as self-justification by the author, who presents the visit by a head of state as a reason for the fact that these important meetings failed to materialize. This report also mirrors the opposite situation: not all the Solidarity Committee's interlocutors were happy about their relations with the Soviet side. They demanded access to more senior, "more official" representatives of the party or the state, not with those of the "Soviet public." One interlocutor expressed "displeasure that there were parties and movements of the first rate, who had direct relations with the central committees in power [sic] and others, of the second rate, who were dealt by the Solidarity

62. Michel Foucault, Psychiatric Power (New York: Picador), 77.

63. GARF f. 9540, op. 1, d. 320a, Otchet o prebyvanii v SDR delegatsii SKSSAA [Report on the stay of the SKSSAA delegation in the Somali Democratic Republic], 1. 33-38.

64. Ivan P. Konovalov, Raspad gosudarstva i grazhdanskaia voina v Somali [State failure and civil war in Somalia], (M.: SPM), 18. Relations collapsed in 1977 with abrogation of the friendship treaty and the outbreak of the Ogaden war, cf. Westad, Global Cold War, 273. Robert Patnam, "Ideology, Soviet Policy and realignment in the Horn", in Adeeb Dawisha \& Karen Dawisha, The Soviet Union in the Middle East (London: Heinemann, 1982), 53. 
Committees." ${ }^{65}$ Aleksandr Dzasokhov notes in his memoirs that Yasser Arafat had also complained about not being introduced to Leonid Brezhnev. Eventually, on short notice, he was "rushed like a bullet from a gun" from the Friendship University in Moscow's southern outskirts to the Kremlin for a face-to-face with Brezhnev. ${ }^{66}$ Thus, both the Solidarity Committee and its partners could perceive each other as deficient diplomats and consider that this kind of diplomacy was not recognised as "the real thing."

Finally, another detailed report was written by a SKSSAA delegation to the Arab Peoples' Conference of Solidarity with the Palestinian Resistance Movement (PRM) held in late 1972 in Beirut. The SKSSAA delegation had an observer status at this conference and was headed by Evgenii Primakov, who was not a member of the SKSSAA. In this report, divisions within the Arab camp, which worried the Soviet observers, are a dominating theme. For example, Libyan representatives refused to participate in the preparatory work of the conference, deeming the planned event to be pro-communist. Also, the Syrian Baath party failed to show-up at the conference. ${ }^{67}$ Discussions erupted around UNSCR 242, ${ }^{68}$ which was supported by the USSR. Primakov and his fellow Soviet observers did not hide their disappointment: these "debates provide a basis for the conclusion that an overwhelming majority of the revolutionary-democratic forces of the Arabian East [...], the liberation movements of the Arabian Peninsula and the Persian Gulf, as well as many Palestinian organisations represent at this moment left-wing extremist positions regarding the Middle East peace process." ${ }^{169}$ While left-wing extremism was a catchphrase in Soviet jargon and research, ${ }^{70}$ it seems odd in the context of the Peace process. In any event, this points to a major distancing from certain movements and questioning of their socialist credentials. This was particularly true for Naif Hawatmeh, leader of the Popular Democratic Front for the Liberation of Palestine (PDFLP), but also for George Habash, ${ }^{71}$ leader of the Popular Front for the Liberation of Palestine (PFLP). "Notwithstanding a certain ideological affinity

65. FRELIMO representative Sérgio Vieira, 1969, quoted in Natalia Telepneva, Our Sacred Duty: The Soviet Union, the Liberation Movements in the Portuguese Colonies, and the Cold War, 1961-1975 (London: The London School of Economics and Political Science, 2014, PhD thesis), 204, http://etheses.lse.ac.uk/id/eprint/3081.

66. Dzasokhov, Chelovek, 48.

67. GARF f. 9540, op. 1, d. 320a, Otchet delegatsii SKSSAA na Arbaskuiu konferentsiiu solidarnosti s palestinskim dvizheniem soprotivleniia [Report of the SKSSAA delegation at the Arab solidarity conference with the Palestinian Resistance Movement], 1. 44-52.

68. UNSCR 242 was endorsed by the PLO only in 1988, see William C. Cleveland \& Martin Bunton, A History of the Modern Middle East (Boulder: Westview, 2009), 360.

69. GARF f. 9540, op. 1, d. 320a, 1. 46.

70. Vladimir F. Li, Partii i revoliutsionnyi protsess v stranakh Azii i Afriki [Parties and revolutionary process in Asian and Africa] (M.: Nauka, 1983), 84-101.

71. On Habash, Primakov even notes that he was a "lefty to his core" (levakom do mozga kostei); Yevgeny Primakov, Russia and the Arabs (New York: Basic Books, 2009), 235; Evgenii Primakov, Konfidentsial'no: Blizhnii Vostok na stsene i za kulisami [Confidential: The Middle East on stage and behind the scene] (M.: Rossiiskaia Gazeta, 2006), 238. 
with [...] Habash and [...] Hawatmeh, Moscow always preferred [...]'Arafat's Fatah - since the Soviet leaders were repulsed by [their] extremism."72 Furthermore, the conference took place after Arafat had expressed his agreement to a two-state solution, much to Primakov's satisfaction. ${ }^{73}$ Accordingly, Primakov's conference report was negative in regards to Hawatmeh and Habash, and positive about Arafat. The former's features included, according to the report written by Primakov in December 1972, "blatancy, dogmatism, an inclination to appeal to well-known positions of scientific Socialism, and, at the same time, an inability to draw consequences from these general positions relating to the concrete conditions of the movement." 74 Still, the Soviet observers recommended cooperating with all these organisations, including the PDFLP, notwithstanding its depiction as irrational and untrustworthy. An opposite assessment was made of the Palestinian Liberation Organisation as a whole, particularly its strongest faction, the Fatah. It culminated in a positive stance towards the opening of the Palestinian "embassy" in Moscow, still "under [pri] the SKSSAA," that is, not affiliated with the Foreign Ministry or the Soviet state, but with the Solidarity Committee - which increased the SKSSAA's diplomatic standing. ${ }^{75}$

In any case, Primakov suggested sponsoring all organisations gathered under the umbrella of the PRM, organising visits in the USSR, "for vacation or medical treatment," and filling the quotas at the Institute of Social Sciences (ION) as well as the Higher Komsomol School (VKSh).$^{76}$ Hence, what we have here is a careful assessment of individuals and movements, which were placed in different categories and for which various measures were proposed to bring the Arab and Soviet sides closer together. Thus, despite the disparities he vividly portrayed in the 'report, Primakov proposed measures glossing over differences.

Of prime interest was evidently the question as to which degree the movements were or not considered revolutionary. Revolution was the foster-child of the Solidarity Committee as it was the core business of most of its partners - at least outwardly, in their interaction with the Soviet Union. Thus, the SKSSAA was possibly the most "revolutionary" of all Soviet organisations in the Soviet Union in the 1970s, as it pretended to firmly believe in revolutionary movements worldwide. As such, it played a key role in the competition with China for the role of revolutionary centre. ${ }^{77}$ Letters from the SKSSAA routinely confirmed the revolu-

72. Vasiliev, Russia's Middle East Policy, 271.

73. Primakov, Russia and the Arabs, 231-232.

74. GARF f. 9540, op. 1, d. 320a, 1. 50.

75. Indeed, the status of the PLO's "embassy" turned out to be very similar to that of a full-fledged diplomatic representation, very much like that of SWAPO's Moscow offices, cf. Vladimir Shubin, The Hot Cold War (London: Pluto, 2008), 231.

76. GARF f. 9540, op. 1, d. 320a, 1. 51.

77. "In the 1960s and 1970s, Beijing [...] promoted itself as a new center of world revolution [...] This was a flexible Marxism attendant to local, indeed individual conditions rather than Soviet directives [...] well-suited to non-Western societies", Steven S. Lee, The Ethnic Avant-Garde, 185-186. However, the USSR and China promoted different models of revolution 
tionary credentials of its interlocutors because this provided them with legitimacy at home and strengthened the grounds for their collaboration with the SKSSAA. They also demonstrated the need for the SKSSAA to engage with them. Thus, both sides needed this confirmation and entered a form of symbiosis: revolution in the East was the raison d'être for both the SKSSAA and its partners. Affirming revolution, however, was not an obvious thing to do. In the 1970s, Western scholars such as Bernard Lewis, who might have had a different kind of revolution in mind generally, questioned the possibility of such an event in the Islamic World, as Arabs would "rise like a camel" at best. ${ }^{78}$ In the Soviet Union itself, the intellectual mood was not supportive of revolutions. At IMEMO, Nodari Simonia caused a minor scandal when he argued in favour of a capitalist phase as a precondition of socialism. ${ }^{79}$

The SKSSAA did not mince words however and praised the very idea of a small liberation movement in the utmost corner of the Arabic world for its potential to stage "glorious revolutions": the Liberation Movement of Oman (PFLOAG) was praised for having raised the "freedom flag" through the revolution it carried out, marking the "beginning [of a] new life for people masses in liberated territories." No doubt, Oman was in need of transformation, and "under PFLOAG leadership important transformations are being carried out in working masses interests [...] to overcome backwardness opens way to education for peasants and fighters children [sic]." ${ }^{\circ 0}$ Still, Oman was considered "backward" and in need of modernisation and Soviet support. While the "Third World" was on the right track politically, there clearly was a Soviet feeling of superiority in economic, social and possibly cultural terms. Hence, in this regard, there was quite a similar posture in both East and West. This points to the paradox of the Soviet view of the Middle East: the latter was essentially backward, but it was also revolutionary, while the USSR was modern and no longer revolutionary. Eventually, this view turned to be not as contradictory as it may seem, as the East's backwardness allowed the USSR to maintain

and development. Roughly put, Moscow tended to support an anti-capitalist revolution and state-led industrialisation, while Beijing argued for anti-imperialist revolution and agricultural development. In the 1970 s, the USSR had largely taken over much of the Chinese programme, including militant anti-imperialist struggle, Jeremy Friedman, Shadow Cold War (Chapel Hill: University of North Carolina Press, 2015), 1-2, 217-218.

78. Bernard Lewis, "Islamic Concepts of Revolution," 38-39 in P.J. Vatikiotis, ed., Revolution in the Middle East and Other Case Studies (New York: Rowman and Littlefield, 1972).

79. Vladimir G. Khoros, D.B. Malysheva (2002) Vostok-Zapad-Rossiia [East-West-Russia] (M.: Progress-Traditsiia), 13. The scandal was caused by Nodari Simonia, Strany vostokaputi razvitiia [Countries of the East - paths of development] (M.: Nauka, 1975). Simonia thus entered a polemic with Rostislav Ul'ianovskii, who advocated a non-capitalist development, in line with the 1960 Moscow Declaration, cf. Friedman, "Soviet policy in the developing world," 255; Jerry F. Hough, The Struggle for the Third World (Washington: Brookings Institution, 1986), 157; David C. Engerman, The Price of Aid: The Economic Cold War in India (Cambridge: Harvard UP); Steffi Marung, "The provocation of empirical evidence," African Identities, 16, 2 (2017): 176-190.

80. GARF, f. 9540, op. 1, d. 373, 1. 48. 
a superior stance vis-à-vis the "Third World" and thus to compensate for the revolutionary advantage many countries seemed to have.

\section{The Solidarity Committee as diplomatic backchannel?}

When there was no socialist revolution to praise, the SKSSAA found other grounds for approval. This approval was given using the language of official Soviet diplomacy. Thus, while the SKSSAA was not an independent diplomatic actor, it could act an additional diplomatic backchannel. At least, it was perceived or used as such by foreign partners, and was itself eager to be seen as such, due to the resulting elevation of its standing among Soviet public organisations. Additionally, according to Karen Brutents, the SKSSAA was the most basic level of Soviet diplomacy, ${ }^{81}$ and former Soviet ambassador to Jordan, Alexei Voronin, confirmed that the Solidarity Committee was the International Department's arm in dealings with public organisations in the Middle East and Africa. ${ }^{82}$ Organizations such as the PLO, SWAPO, or the ANC, were taken "under the wing" of the Solidarity Committee. ${ }^{83}$ Two examples confirm that the SKSSAA fulfilled a backchannel diplomatic function. ${ }^{84}$

On the second anniversary of the Iraqi-Soviet friendship treaty, in 1974, Aleksandr Dzasokhov held a congratulatory speech that well reflected official Soviet positions. This was the honeymoon phase in Soviet-Iraqi relations, which were doomed to deteriorate after Baghdad resumed the conflict with the Kurds in 1975 and unleashed a campaign against the Iraqi communists in $1978 .{ }^{85}$ For Galia Golan, it was always Iraq that determined the character of the relationship, ${ }^{86}$ and Viktor Posuvaliuk even argues that Iraq and the USSR had never been "real allies." 87 In 1974, however, Iraq still enjoyed good standing in Moscow and ties were close, in the cultural and educational spheres as well. ${ }^{88}$ Accordingly, Dzasokhov was full of praise for Soviet-Iraqi friendship and Iraq's policies. First, he established that Iraqi-Soviet friendship was placed in the context of a long anti-imperialist fight, fulfilling tasks in line with a "worldwide revolutionary process." Within

81. Brutents, Tridtsat' let, 375.

82. Vasil'ev, Rossiia na blizhnem i srednem vostoke, 238. Voronin, who was ambassador in Amman from 1972 to 1978, also stresses the regular consultations he had with Dzasokhov.

83. Vasil'ev, Russia's Middle East Policy, 271.

84. Though the SKSSAA did not engage in a veritable "track 2" diplomacy, as defined by Davidson, W.D., \& J.V. Montville, "Foreign Policy According to Freud," Foreign Policy, 45 (1981-1982): 145-157.

85. Primakov, Russia and the Arabs, 304-309.

86. Golan, Soviet Policies in the Middle East, 174.

87. Viktor Posuvaliuk, Bagrovoe nebo Bagdada [Baghdad's crimson sky] (SPb.: Aleteiya, 2012), 110.

88. Katsakioris, "Soviet Lessons for Arab Modernization." 
a short period of time, the national liberation struggle of Iraq realised considerable achievements and changed the social-economic set-up of "ancient Mesopotamia." The "July revolution" of 1958 toppled an "archaic feudal regime" and after the 1968 takeover by the Baath party, the government took, according to Dzasokhov, progressive steps, among which he highlighted the creation of a national petrol sector, an agrarian reform and improvements for the workers ${ }^{89}$ Dzasokhov returned to the Kurdish issue, which was to be solved democratically, and the unity of the progressive forces, including the Communist party of Iraq. ${ }^{90}$ Thus, Dzasokhov did not question the revolutionary dimension of the 1958 army coup, which had allegedly been supported by "huge popular masses," albeit this revolution was not socialist and more national and modernising in character. This seemed revolutionary enough to him. ${ }^{91}$ In short, Dzasokhov left few doubts about the general direction of development in Iraq specifically and in the other Arab states in general. While the brief hint at the situation in Kurdistan and the building of a broad party coalition including the Iraqi Communist party may be seen as a veiled admonishment, by and large, Dzasokhov expressed satisfaction with the state of bilateral affairs. Most importantly, he placed Soviet-Arab friendship in the global context of an on-going Arab revolution, of which the Soviet Union and the socialist bloc were the most important expressions. With this speech, Dzasokhov also seemed to leave the field of backchannel diplomacy and engage in an emulation of diplomacy proper: he appeared as a state representative on the occasion of the celebration of a treaty between two states.

Foreign partners equally treated the Solidarity Committee as a backchannel to Soviet foreign policy. While some complained about dealing exclusively with the SKSSAA and not with "real" Soviet diplomats, as mentioned above, some exploited the connection with the Solidarity Committee as best they could to further their cause. In turn, this certainly flattered the SKSSAA as it reaffirmed its status. A left-wing activist from Mauritius, for example, complained that every "progressive Mauritian who pays a friendly visit to the Embassy is subject to punishment" by local authorities. "This is why we cannot turn to the Soviet Embassy and hope that you understand our real situation." 92 The author of the letter, "Miss Keeno," representing the People's Progressive Party of Mauritius, then went on to complain about the way China furthered the spread of Maoism on Mauritius. In doing so, Miss Keeno argued that Beijing had adopted the very techniques used by the

89. GARF f. 9540, op. 1, d. 373, Doklad otvetstvennogo sekretaria SKSSAA, Dzasokhova, A.S., posviashchennyi vtoroi godovshchine podpisaniia dogovora o druzhbe i sotrudnichestve mezhdu SSSR i Irakskoi Respublikoi, 1974 [Lecture by Acting SKSSAA Secretary A. Dzasokhova honouring the second anniversary of the signing of the Friendship Treaty between the USSR and the Republic of Iraq], 1. 69-70, here: 1. 61-62.

90. GARF f. 9540, op. 1, d. 373, 1. 63-64.

91. GARF f. 9540, op. 1, d. 373, 1. 66.

92. GARF, f. 9540, op. 1, d. 328, Perepiska s natsional'nymi komitetami solidarnosti stran Azii i Afriki [Correspondence with national solidarity committees in Asia and Afrika], 1.1.-31.12.1972, 1. 39-40. 
Soviet Union: sponsoring trips to China under the guise of cultural relations. Miss Keeno concluded by asking for printed material and support in educational matters. A letter like this contained everything the SKSSAA wanted to see: the embassy alone could not produce an accurate picture of the situation in the country, China was expanding dangerously into the "Third World," and progressive activists requested exactly that kind of help that the SKSSAA could readily offer - printed material on the USSR, support in education - and, most importantly, those requests allowed the SKSSAA to act as a bulwark against China. At the same time, such letters had to be treated with great care. Though a small country, Mauritius in the 1970s had a variety of left-wing organisations, such as the Mauritius Communist Party, the Mauritius Young Communist League, or the Mauritius Liberation Front. They likely all tried to be on good terms with Moscow (or Beijing or both), blaming the others of conspiring with the Chinese or of being less reliable or faithful to the USSR. ${ }^{93}$ The claim advanced here and confirmed by the sources quoted above is not that the SKSSAA could conduct independent diplomatic activity, but rather that it was perceived by some actors as a diplomatic channel, that the Solidarity Committee itself reproduced positions of Soviet official diplomacy and that it claimed a diplomatic role.

\section{Conclusions}

In line with the New Cold War History and Global History, this paper has discussed the interactions between the SKSSAA and its partners in the 'foreign East' beyond the framework of bipolar confrontation. It has taken the discussion of Soviet Orientalism as a point of departure, providing another example for the multiplicity and historicity of Orientalism and highlighting its importance for understanding the USSR's external relations. As the instances above have demonstrated, the Solidarity Committee and its interlocutors developed a certain dynamic and entered a form of symbiosis in which they depended upon one another and in which they developed a common language and terminology. This interdependency is a peculiar feature of Soviet Orientalism. In this Soviet-type Orientalism, the Soviet Self is in a powerful position to judge, assess, provide or withhold support, and to make authoritative statements about the Other. Still, the Other is continuously deemed as having the potential to become similar to the Soviet Self. It is even expected to live up to Soviet standards in order to qualify for Soviet support.

This interdependency is especially visible in the identity-crafting dimension of the interaction between the SKSSAA and its partners. The Solidarity Committee repeatedly cast common enemies, such as the West and Israel. It was very keen to place the Soviet Union in the same boat as the Middle Eastern liberation

93. Turning to China could have various reasons depending on context: for example, Albania's turn to China had mainly economic reasons; China, for its part, considered aid for "ideological reasons" alone to have "too big a price tag [...] in the long term", cf. Lorenz Lüthi, The SinoSoviet Split (Princeton: Princeton UP, 2008), 204-205. 
movements, claiming imperial domination to be an enemy of both the Soviet Union and the Middle East. The SKSSAA also strove to present itself as a champion of Arab unity and of unity within Arab states, such as between the Kurds and the Iraqi central government. This was in line with Soviet official positions. A major task consisted in continuously assessing its partners. SKSSAA memos were written from an authoritative position, judging Middle Eastern movements and partners from an omniscient perspective. Assessments also evaluated individuals and their behaviour, habits, and demeanour. They could go into personal details, indicating, for example whether an individual was or not prone to drinking, evaluating their knowledge of Marxism, or stating whether the person was an extremist. A special gauge of assessment was the Middle Eastern partners' revolutionary potential. However, as seen in the report written for the SKSSAA by Evgenii Primakov, one could also be too left-wing or revolutionary, which confirmed the moderating position that the Soviet Union wished to assume in the 1970s.

Advocating a balanced position in the Middle East was in line with the tenets of official Soviet foreign policy, especially of Détente. The aim of this paper is not to claim that the SKSSAA conducted independent backchannel diplomacy, as it remained dependent on the Party's International Department. Rather, the documents under scrutiny show two things: first, the Solidarity Committee was an additional channel through which the Soviet Union could divulge its official positions. It provided a niche of communication. Second, this channel also worked the other way around. For some movements, the SKSSAA was possibly the only interlocutor providing access to Soviet foreign policy. These reports, which confirmed this function of the Solidarity Committee, were possibly especially well regarded within the ranks of the SKSSAA, as they could demonstrate (also within the USSR) the Committee's important role in foreign relations. The position of the Solidarity Committee as foreign policy player is confirmed by the fact that, for example, copies of many reports written by Soviet embassies were not only sent to the Middle East section of the Ministry of Foreign Affairs but also to the International Department of the CPSU and the SKSSAA. This is not to say that the SKSSAA directly influenced the decision-making of the Ministry of Foreign Affairs or of the CPSU. It was an additional vehicle of foreign policy positions for the Soviet Union and a means for various movements to demonstrate their allegiance to the USSR. From the perspective of Orientalism, it is important to note that the SKSSAA functioned as an additional source of knowledge. It gathered, analysed and processed information about its partners and produced knowledge about the "Third World". It ranked its partners according to varying categories, especially their revolutionary potential, or their position on a left-right scale within leftism, produced reports, evaluations, and memos. It did so from a position of supremacy, in its enduring roles as the inviter, observer, decider, evaluator - and it was the organisation that decided about funding such things as grants, travel expenses, and medical trips to the Soviet Union.

However, the Solidarity Committee also needed recognition from its partners, and this was the point where Soviet Orientalism became a peculiar variant, 
deviating from what has been broadly described for Western societies. "Revolution" was literally the SKSSAA's business. It needed reliable and at least formally revolutionary partners. Their existence was proof of the Solidarity Committee's success, their absence or decline symbolised its failure. However, they should not succeed too much, as this would catapult them out of the responsibility of the Solidarity Committee and into the field of official Soviet diplomacy: when Palestine was proclaimed as a state in 1988, responsibility for the PLO was transferred to the Foreign Ministry. However, the very possibility of the Middle East being revolutionary was another departure from most Western assumptions about the East. By being revolutionary, the East could become similar to the Soviet Self. The Middle East and the "Third World," especially as embodied by liberation movements, could become a place where the socialist revolution could continue. Against all the scepticisms within the foreign policy establishment and the Academy of Sciences in the 1970s, the Solidarity Committee considered that there still was a truly "combative, mobilising mood" in the developing world. ${ }^{94}$ While such pronouncements were rather rare in official documents as the role of ideology decreased, ${ }^{95}$ this was the tenor in public statements and in the popular mouthpiece of the Solidarity Committee, Aziia i Afrika segodnia. To its readers, revolution was still going on in the foreign East, thus providing a counterbalance to the lack of revolution, emancipation or liberation that characterised the Stagnation in the $\mathrm{USSR}^{96}$ in late socialism.

\section{University of Basel}

ph.casula@unibas.ch

94. GARF, f. 9540, op. 1, d. 320a, Otchety ob uchastii sovetskoi delegatsii v rabote 12. sessii Ispolnitel'nogo komiteta OSNAA 1972 [Reports of on the participation of the Soviet delegation to the $12^{\text {th }}$ session of the Acting OSNAA Committee], 1. 7.

95. Katsariokis, “Une superpuissance,” 119.

96. "The absence of the emancipatory potential of struggle for liberation, the absence of workers' rights, the absence of an original national culture", was typical for late socialism in other countries as well and pushed, for example, Yugoslav artists to seek new forms of expression, cf. Zdenka Badovinac, "Introduction," in Zdenka Badovinac, ed., From Kapital to Capital (Ljubljana: Moderna galerija), 7. 
